\title{
Autoantibodies to Novel Cytoplasmic Structures (GW bodies) Involved in mRNA Processing
}

\author{
Mittermayer Santiago $^{(1)}$, Theophany Eystathioy(2), Rahima Bhanji ${ }^{(2)}$, Marvin J. Fritzler ${ }^{(2)}$
}

\section{INTRODUCTION}

This particular cytoplasmic discrete speckled pattern $(1,2)$ is quite unique as the structures observed are a new entity named GW bodies (Figure 1), abbreviated GWBs (also known as mammalian $\mathrm{P}$ bodies or processing bodies). Functionally, GWBs are involved in the process of RNA interference (RNAi), mRNA degradation and/or mRNA storage. A subset of mRNAs are targeted to these cytoplasmic structures, therefore GWBs play a central role in the cell by influencing the fate of mRNAs. GWBs are ubiquitous and present in many tissues and cell lines as well as normal cells but appear to be more highly expressed in cancer cells such as HEp-2 (laryngeal carcinoma) and HeLa (cervical carcinoma) that are now routinely used to screen human sera for the presence of autoantibodies.

To date, five target autoantigens in GWBs have been published. They include GW182, a unique protein characterized by a numerous glycine $(\mathrm{G})$ and tryptophan $(\mathrm{W})$ repeats $^{(3)}$, Ge-1/hedls ${ }^{(4,5)}$, RAP-55 ${ }^{(6)}$, diacyl-phosphatidyl ethanolamine ${ }^{(2)}$, and $\mathrm{Su} / \mathrm{hAgo} 2^{(7)}$.

The clinical diagnosis of patients with autoantibodies to GWBs can be divided into four main groups. In a study from the University of Calgary, the most common diagnosis is Sjögren's syndrome, systemic lupus erythematosus (SLE), and the third group has neurological disease ${ }^{(3)}$. In another study from Brazil ${ }^{(2)}$ there was no clear cut clinical associations, although 3 patients with SLE were noted, but the majority comprise the fourth category of other conditions $^{(2)}$. The difference between the clinical profiles in these two centers may be explained on the basis of different clinical referral patterns. For example, in Calgary, serum samples of patients with suspected autoimmune neurological disease (ataxia, motor and sensory neuropathy) are routinely evaluated. Examination of 5000 patient serum samples received during 2000-2001, by ANA at the Mitogen Advanced Diagnostics Laboratory at the University of Calgary, demonstrated that the prevalence

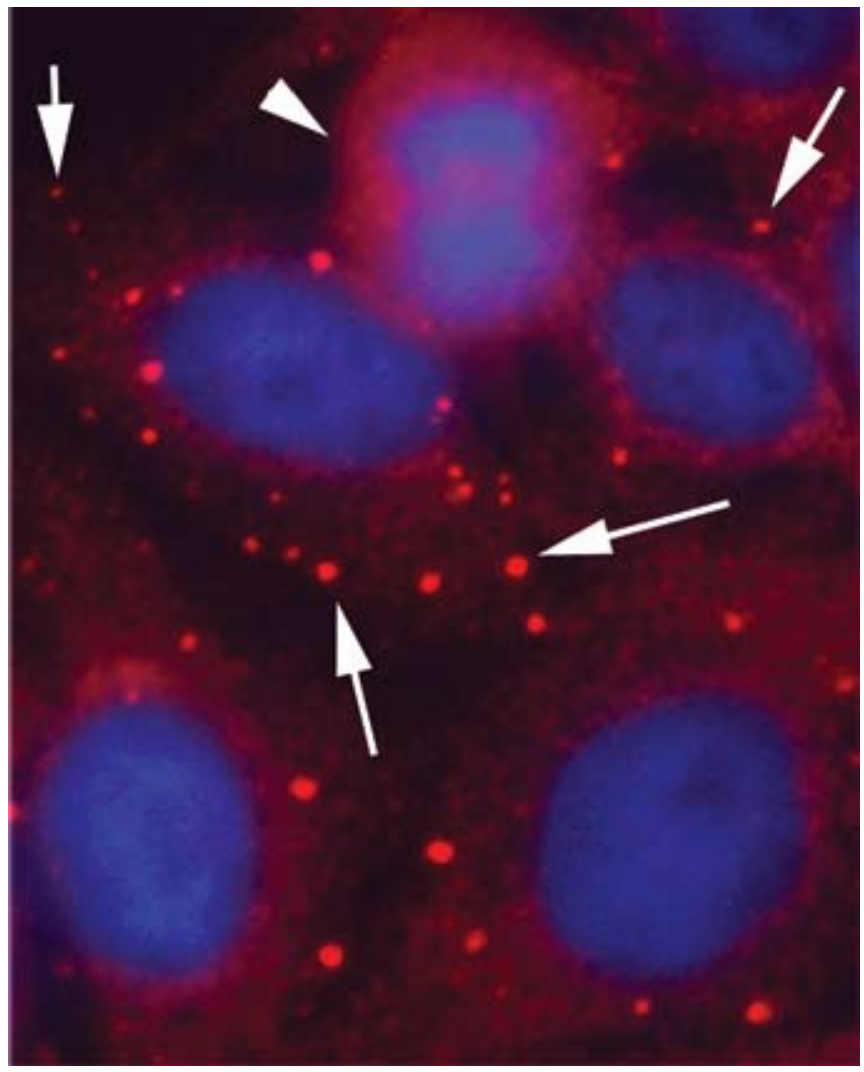

Figura 1 - Hep2000 cells stained with patient serum containing autoantibodies to GWBs (red). The nuclei are stained with DAPI (blue). Arrows are pointing to different sized GWBs while the arrowhead marks a cell undergoing mitosis.

of autoantibodies to GWBs was approximately $0,36 \%$, similar to that observed for anti-Sm antibodies $(0,4 \%)$, and higher than anti-PCNA antibodies $(0,1 \%)^{(1)}$. The specificity of anti-GWB antibodies in the aforementioned diseases, in addition the prognostic, diagnostic value and pathogenic role of these autoantibodies remains to be determined. In addition, autoantibodies to components of the RNA interference and mRNA processing pathway represents an additional unique subset of autoantibodies to a family of macromolecuales characterized as RNAprotein complexes $^{(8)}$. 


\section{REFERÊNCIAS}

1. Stinton LM, Eystathioy T, Selak S, Chan EKL, Fritzler MJ: Autoantibodies to protein transport and messenger RNA processing pathways: Endosomes, lysosomes, Golgi complex, proteasomes, assemblyosomes, exosomes and GW Bodies. Clin Immunol 110: 30-44, 2004.

2. Laurino CFC, Fritzler MJ, Mortara RA, Silva NP, Almeida IC, Andrade LEC: Human autoantibodies to diacylphosphatidylethanolamine recognize a specific set of discrete cytoplasmic domains. Clin Exp Immunol 143: 572-84, 2006.

3. Eystathioy T, Chan EKL, Yang Z, et al: Clinical and serological associations of autoantibodies to a novel cytoplasmic autoantigen, GW182 and GW bodies. J Mol Med 81: 811-8, 2003.
4. Bloch DB, Yu JH, Yang WH, et al: The cytoplasmic dot staining pattern is detected in a subgroup of patients with primary biliary cirrhosis. J Rheumatol 32: 477-83, 2005.

5. Yu JH, Yang WH, Gulick T, Bloch KD, Bloch DB: Ge-1 is a central component of the mammalian cytoplasmic mRNA processing body. RNA 11: 1795-802, 2005.

6. Yang WH, Yu JH, Gulick T, Bloch KD, Bloch DB: RNAassociated protein 55 (RAP55) localizes to mRNA processing bodies and stress granules. RNA 12(4): 547-54, 2006.

7. Jakymiw A, Ikeda K, Fritzler MJ, Reeves WH, Satoh M, Chan EK: Autoimmune targeting of key components of RNA interference. Arthritis Res Ther 8: R87, 2006.

8. Pruijn GJM: The RNA interference pathway: a new target for autoimmunity. Arthritis Res Ther 8: 110-2, 2006. 